\title{
Different environmental gradients affect different measures of snake $\beta$-diversity in the Amazon rainforests
}

\author{
Rafael de Fraga ${ }^{\text {Corresp., }}{ }^{1,2,3}$, Miquéias Ferrão ${ }^{1}$, Adam J Stow ${ }^{2}$, William E Magnusson ${ }^{4}$, Albertina P Lima ${ }^{4}$ \\ 1 Programa de Pós-Graduação em Ecologia, Instituto Nacional de Pesquisas da Amazônia, Manaus, Amazonas, Brazil \\ 2 Department of Biological Sciences, Macquarie University, Sydney, New South Wales, Australia \\ 3 Programa de Pós-graduação em Sociedade, Natureza e Desenvolvimento, Universidade Federal do Oeste do Pará, Santarém, Pará, Brazil \\ ${ }^{4}$ Coordenação de Biodiversidade, Instituto Nacional de Pesquisas da Amazônia, Manaus, Amazonas, Brazil \\ Corresponding Author: Rafael de Fraga \\ Email address: r.defraga@gmail.com
}

Mechanisms generating and maintaining biodiversity at regional scales may be evaluated by quantifying $\beta$-diversity along environmental gradients. Differences in assemblages result in biotic complementarities and redundancies among sites, which may be quantified through multi-dimensional approaches incorporating taxonomic $\beta$-diversity (TBD), functional $\beta$-diversity (FBD) and phylogenetic $\beta$-diversity (PBD). Here we test the hypothesis that snake TBD, FBD and PBD are influenced by environmental gradients, independently of geographic distance. The gradients tested are expected to affect snake assemblages indirectly, such as clay content in the soil determining primary production and Height Above the Nearest Drainage (HAND) determining prey availability, or directly, such as percentage of tree cover determining availability of resting and nesting sites, and climate (temperature and precipitation) causing physiological filtering. We sampled snakes in 21 sampling plots, each covering $5 \mathrm{~km}^{2}$, distributed over $880 \mathrm{~km}$ in the central-southern Amazon Basin. We used dissimilarities between sampling sites to quantify TBD, FBD and PBD, which were response variables in multiple-linear-regression and RDA models. We show that patterns of snake community composition based on TBD, FBD and PBD are associated with environmental heterogeneity in the Amazon. Despite positive correlations between all $\beta$-diversity measures, TBD responded to different environmental gradients compared to FBD and PBD. Our findings suggest that multi-dimensional approaches are more informative for ecological studies and conservation actions compared to a single diversity measure. 
1 Different environmental gradients affect different measures of snake $\beta$-diversity in the

2 Amazon rainforests

3

4 Rafael de Fraga ${ }^{1,2,3^{*}}$, Miquéias Ferrão ${ }^{1}$, Adam J. Stow ${ }^{3}$, William E. Magnusson ${ }^{4}$, Albertina P. 5 Lima $^{4}$

6

$7{ }^{1}$ Programa de Pós-graduação em Ecologia, Instituto Nacional de Pesquisas da Amazônia,

8 Manaus, Amazonas, Brazil

$9{ }^{2}$ Programa de Pós-graduação em Sociedade, Natureza e Desenvolvimento, Universidade Federal

10 do Oeste do Pará, Santarém, Pará, Brazil

$11{ }^{3}$ Department of Biological Sciences, Macquarie University, Sydney, New South Wales,

12 Australia

$13{ }^{4}$ Coordenação de Biodiversidade, Instituto Nacional de Pesquisas da Amazônia, Manaus,

14 Amazonas, Brazil

$15{ }^{*}$ corresponding author: Rafael de Fraga r.defraga@gmail.com

16

17

18

19

20

21

22

23 


\section{Abstract}

Mechanisms generating and maintaining biodiversity at regional scales may be evaluated by quantifying $\beta$-diversity along environmental gradients. Differences in assemblages result in biotic complementarities and redundancies among sites, which may be quantified through multidimensional approaches incorporating taxonomic $\beta$-diversity (TBD), functional $\beta$-diversity (FBD) and phylogenetic $\beta$-diversity (PBD). Here we test the hypothesis that snake TBD, FBD and PBD are influenced by environmental gradients, independently of geographic distance. The gradients tested are expected to affect snake assemblages indirectly, such as clay content in the soil determining primary production and Height Above the Nearest Drainage (HAND) determining prey availability, or directly, such as percentage of tree cover determining availability of resting and nesting sites, and climate (temperature and precipitation) causing physiological filtering. We sampled snakes in 21 sampling plots, each covering $5 \mathrm{~km}^{2}$, distributed over $880 \mathrm{~km}$ in the central-southern Amazon Basin. We used dissimilarities between sampling sites to quantify $\mathrm{TBD}, \mathrm{FBD}$ and $\mathrm{PBD}$, which were response variables in multiplelinear-regression and RDA models. We show that patterns of snake community composition based on TBD, FBD and PBD are associated with environmental heterogeneity in the Amazon. Despite positive correlations between all $\beta$-diversity measures, TBD responded to different environmental gradients compared to FBD and PBD. Our findings suggest that multidimensional approaches are more informative for ecological studies and conservation actions compared to a single diversity measure. 


\section{Introduction}

Investigating how environmental gradients influence community structure is crucial to

understanding mechanisms and processes affecting biodiversity at different scales (Keddy, 1992).

50 Quantifying species-habitat associations across continuous landscapes helps disentangle the

51 mechanisms generating and maintaining patterns of regional and local biodiversity. This has

52 been widely demonstrated in the Amazon rainforests by estimates of assemblage $\beta$-diversity

53 associated with environmental gradients at mesoscales (e.g., Drucker, Costa \& Magnusson,

54 2008; Fraga, Lima \& Magnusson, 2011; Bueno et al., 2012; Ribeiro-Jr, Lima \& Magnusson,

55 2012; Rojas-Ahumada, Landeiro \& Menin, 2012; Moulatlet et al., 2014; Menger et al., 2017). In

56 general, levels of $\beta$-diversity across heterogeneous continuous landscapes has been estimated

57 through biotic complementarities and redundancies among sites. Most studies focused on

58 measures of $\beta$-diversity based on between-site dissimilarities in quantitative (based on abundance

59 data) and qualitative (presence/absence data) species composition. However, use of multiple

60 dimensions may be more informative, because different diversity measures often carry

61 complementary information (Devictor et al., 2010; Weinstein et al., 2014).

62 Numerous methods have been developed to quantify $\beta$-diversity, and each method

63 potentially gives different insights into the mechanisms driving biodiversity (Dehling et al.,

64 2014). Values of taxonomic $\beta$-diversity (TBD) may change across heterogeneous landscapes in

65 response to variation in availability of resources, because of selection for different physiological

66 characteristics, ecological plasticity, intra and interspecific interactions, and dispersal ability

67 (Mariac et al., 2011; Hangartner, Laurila \& Räsänen, 2012). In general, patterns of community

68 assembly are caused by different portions of environmental gradients providing suitable 
69 conditions to habitat-specialist species, while generalists cover larger portions of gradients (e.g., 70 Kinupp \& Magnusson, 2005).

71 Estimates of functional $\beta$-diversity (FBD) may change across heterogeneous landscapes

72 because function is mediated by phenotypes potentially affecting the species performance and

73 fitness, such as morphological, biochemical, behavioral and phenological traits (Petchey \&

74 Gaston, 2002). Functional traits can be environmentally filtered when environmental

75 heterogeneity is sufficient to cause variation in local adaptation to different selection pressures

76 (Weinstein et al., 2014). Additionally, some traits such as foraging mode may determine the

77 ability of snakes to cross different habitat patches in Amazonia (Fraga et al., 2017). High levels

78 of FBD are often related to ecosystem dynamics, stability and productivity (Tilman, 2001).

79 Estimates of phylogenetic $\beta$-diversity (PBD) usually incorporate information on the

80 evolutionary history that is shared among species throughout assemblages (Milcu et al., 2013).

81 High values of PBD suggest convergent adaptation among historically isolated assemblages, but 82 recently connected (Weinstein et al., 2014), which is expected as a result from timescale 83 variation in stability and connectivity among habitat patches (Morlon et al., 2011; Jetz \& Fine, 84 2012). In the Amazon rainforests, a combination between the Andean uplift and climate change 85 are though as major factors driving habitat evolution, and consequently driving species 86 diversification, dispersal and extinction (Hoorn et al., 2010). Alternatively, levels of PBD 87 positively related to FBD suggest assemblages evolutionary structured by niche conservatism 88 (Wiens \& Graham, 2005).

89 Measures of $\beta$-diversity based on between-site differences in TBD, FBD and PBD are 90 more effective at identifying factors shaping community structure than measures of $\alpha$-diversity, 91 such as number of species or functional groups at particular sites (Cadotte et al., 2009; Flynn et 
92 al., 2011). This is because mechanisms influencing community assembly act on biotic

93 complementarities and redundancies among sites, and not on the number of organism-units

94 within sites (Diaz \& Cabido, 2001; McGill et al., 2006). In general, $\alpha$-diversity measures fail to

95 capture the contribution of each species to the regional diversity, because different sites may

96 have equal values of diversity (e.g., number of species), even if the species found in each site are

97 taxonomically, functionally or phylogenetically distinct. Identifying mechanisms underpinning

$98 \beta$-diversity has clear implications for conservation management. These include identification of

99 unique characteristics in the regional diversity, which makes a site irreplaceable and therefore a

100 priority for conservation actions (Pressey et al., 1993). This approach has been used to test the

101 efficiency of protected areas in France (Meynard et al., 2011), the effects of forest modification

102 on birds and trees in South Africa (Grass et al., 2015), and the efficiency of environmental law

103 in Brazil (Fraga, Lima \& Magnusson, 2011; Bueno et al., 2012).

104 Although much of the Amazon basin appears relatively homogeneous in satellite images,

105 ecological studies at mesoscales have shown that subtle changes along environmental gradients

106 influence patterns of co-occurrence of frogs (Ribeiro-Jr, Lima \& Magnusson, 2012; Rojas-

107 Ahumada, Landeiro \& Menin, 2012), understory birds (Bueno et al., 2012; Menger et al., 2017),

108 plants (Costa, Magnusson \& Luizão, 2005; Drucker, Costa \& Magnusson, 2008) and snakes

109 (Fraga, Lima \& Magnusson, 2011). In this study, we sampled a continuous landscape across

110 about $880 \mathrm{~km}$ of rainforest, from central to southwest Amazonia. Most species of snakes

111 recorded are widely distributed throughout the Amazon basin and some occur in other

112 ecosystems in South America. However, species do not occupy all sites within their ranges, and

113 different assemblages could be expected even at scales of tens of kilometers (Fraga, Lima \&

114 Magnusson, 2011). The wide distributions indicate that assemblage differences are more likely to 
115 result from environmental effects than from historical contingencies, such as dispersal limitation

116 across geographic barriers.

117 In this study we examine the influence of environmental gradients on TBD, FBD and

118 PBD estimates for snake assemblages in the Amazon rainforests. Investigating multiple

119 assemblage dimensions in the same study system potentially allows accessing broad pictures of

120 factors causing and maintaining biodiversity. Snakes are useful organisms to test for

121 multidimensional changes in assemblages over landscapes in the Amazon because of the

122 exceptionally-high species diversity (e.g., Bernarde et al., 2012), great species-trait diversity

123 (e.g., body size and colors, reproductive and foraging modes), which implies large variation in

124 functional traits (e.g., Martins \& Oliveira, 1999), and heterogeneous habitats that potentially

125 affect dispersal and gene flow (Fraga et al., 2017). In addition, snakes have been included in

126 estimates of global reptile decline (Gibbons et al., 2000), which highlights the importance of

127 assessing a broad picture of mechanisms generating diversity. This is particularly important in

128 the area we sampled, because it is under strong anthropogenic pressure due to rapid urban growth

129 (Soares-Filho et al., 2006; Fraga et al., 2013a), deforestation associated with paving the major

130 access road (Fearnside \& Graça, 2006; Soares-Filho et al., 2006), and flooding by hydroelectric

131 power plants (Fearnside, 2014). Few studies have attempted to identify multiple factors driving

132 snake community assembly (e.g., Fraga, Lima \& Magnusson, 2011). Furthermore, to our

133 knowledge, the standardized sampling effort used over such a large area in this study is

134 unprecedented.

135 We evaluate the effects of environmental gradients on snake assemblages and investigate

136 spatial structuring causing levels of TBD, FBD and PBD among sites. We test the general

137 hypothesis that patterns of community composition in taxonomic, functional and phylogenetic 
138 spaces result from current environmental heterogeneity. Additionally, we hypothesize that

139 different $\beta$-diversity measures should respond to different environmental gradients, because they

140 carry complementary information on snake assemblages.

141

142 Materials \& Methods

143 Snake sampling. We sampled snakes in 21 RAPELD sampling sites (Magnusson et al.,

$1442005,2013)$, each of which has trails covering $5 \mathrm{~km}^{2}$ ( $5 \mathrm{~km}$ separated by $\left.1 \mathrm{~km}\right)$. RAPELD is a

145 Brazilian acronym to accommodate two study scales, rapid assessments (RAP) and long-term

146 ecological research (PELD - in Portuguese, Pesquisas Ecológicas de Longa Duração). RAPELD

147 sampling sites will be mentioned throughout the text as modules.

148 In each module, we sampled ten $250 \mathrm{~m}$ long by $10 \mathrm{~m}$ wide plots with center lines

149 following the altitudinal contours. The plots were distributed along two parallel 5-km long trails

150 (five plots per trail) with standardized distance of $1 \mathrm{~km}$ between neighboring plots. The modules

151 were distributed almost linearly over $880 \mathrm{~km}$ (Fig. 1) from central (Manaus, Amazonas) to

152 southwest Amazonia (Porto Velho, Rondônia). The study area includes Central Amazonia, to the

153 north of the Amazon River, the interfluve between the middle regions of the Madeira and Purus

154 rivers, and the upper Madeira River, in southwestern Amazonia. Three modules were installed at

155 the Ducke Reserve, which is a $100-\mathrm{km}^{2}$ fragment of non-flooded primary rainforest, located on

156 the northern outskirts of Manaus. Eleven modules were installed along the federal highway BR-

157319 that connects Manaus to western Brazil. The highway was largely abandoned in the 1980s,

158 and the modules were installed mainly to enable multi-taxa impact assessments of the effect of

159 the road on biodiversity. Along this road, modules were placed in areas covered by primary and

160 old-secondary rainforest, with patches of flooded forest and campinarana (forest on white sand). 
161 The southern Madeira River region contains seven modules. The Madeira River was recently

162 dammed by two large hydroelectric power plants in the Porto Velho region, and the modules

163 were installed along the banks of the river for monitoring the effects of flooding on biodiversity.

164 The data used in this study were collected prior to flooding (see details below). The region is 165 covered by primary and secondary rainforest under increasing threat of human occupation.

166 We sampled snakes by nocturnal active visual search, with two observers per plot, and

167 standard searching time of 1 hour per plot. In the Amazon, nocturnal search simultaneously

168 allows finding foraging nocturnal species, and resting diurnal species (field observation). To

169 increase the sampling effort and accuracy in species detection, we undertook four non-

170 consecutive surveys of each plot between 2007 and 2014. We show below that temporal

171 variation (e.g., caused by seasonal environmental variables) in assemblage structure is unlikely,

172 because species composition did not differ among the surveys. Snakes were collected under

173 RAN-ICMBio / IBAMA (Ministry of Environment, Government of Brazil) permanent license $n^{\circ}$

174 13777-2/2008 in the name of Albertina Pimentel Lima (coordinator of the sampling expeditions).

175 The license includes ethical approval of all the procedures used.

176 Detection probabilities of snakes are usually very low (Steen, 2010; Fraga et al., 2014),

177 and they may bias the results by generating statistical artifacts such as the arc effect (Gauch,

178 1982), mainly because no species occurrence is shared between sampling units. To avoid

179 statistical artifacts in this study, we used modules as sampling units rather than plots. This results

180 in loss of degrees of freedom, but it increases the predictive power of the analysis because the

181 sampling units usually shared more than one species. All the analyses in this study are based on

18226 species (Table S1), belonging to four families (Boidae, Colubridae, Dipsadidae and

183 Viperidae). 
185 (Principal Coordinates Analysis) ordination of a matrix of Forbes' similarity index (Forbes,

186 1907) on species presence/absence data between modules. We transformed Forbes' similarities

187 in dissimilarities between modules by 1 - Forbes. The Forbes index has been indicated as robust

188 in the case of incomplete sampling (Alroy, 2015), which is common in studies of snakes in the

189 Amazon due to the low detection probabilities of most species (Fraga et al., 2014). The PCoA

190 was undertaken in the vegan package (Oksanen et al., 2015) in R (R Development Core Team, 191 2015).

192 Functional B-diversity (FBD). We constructed a trait matrix using ten continuous and

193 discrete traits, measured or observed for adult individuals only. These were maximum total

194 length, tail length proportional to body length, diameter of the eye proportional to head length, 195 maximum size of offspring, discrete habitat (aquatic, arboreal, cryptozoic, fossorial, terrestrial),

196 period of activity (diurnal, nocturnal), foraging mode (ambush, active), diet (birds, bird eggs,

197 centipedes, earthworms, frogs, fish, lizards, mammals, snails, snakes, Squamata eggs, tadpoles),

198 defensive behavior (ball posture, bite, caudal autotomy, cloacal discharge, constriction, enlarged

199 head, flattened body, hidden head, inflated neck, liana imitation, shown mucosa, sound, strike,

200 tail shaking, tail sting, venom, vomit) and reproductive mode (oviparous, viviparous). All the

201 traits used have been described as ecologically relevant for snakes (literature compilation in

202 Burbrink \& Myers, 2015). Further details on functional traits may be found in Table S2.

203 The continuous traits were measured, and we used average values per species (see

204 Petchey \& Gaston, 2006). For the species for which we found less than five individuals, we

205 supplemented our data with published data (Beebe, 1946; Belluomini \& Hoge, 1958; Duellman,

206 1978; Cunha \& Nascimento, 1983; Dixon \& Soini, 1986; Michaud \& Dixon, 1989; Cunha \& 
207 Nascimento, 1993; Starace, 1998; Martins \& Oliveira, 1999; Fraga et al., 2013a). We also

208 obtained most of the data for discrete traits per species from the literature, and they were

209 supplemented with field observations. The levels of most discrete traits are not mutually

210 exclusive (e.g. species which feed on a variety of prey), so we coded discrete traits into

211 independent binary traits as suggested by Petchey \& Gaston (2007).

212 We used the trait matrix to estimate FBD using the dFBD function in the FD R-package

213 (Laliberté \& Legendre, 2010; Laliberté, Legendre \& Shipley, 2014). This function calculates

214 Gower distances between species, which is an index thought to be more appropriate when

215 analyzing mixed continuous and discrete traits, although the results are often strongly correlated

216 with Euclidean distances (Petchey \& Gaston, 2007). The dFBD function transforms the Gower

217 distance matrix by calculating square roots. This is important to avoid negative eigenvalues in

218 the PCoA calculated from the distance matrix, which should be set in Euclidean space to avoid

219 biased estimates of FD (Laliberté \& Legendre, 2010). PCoA was used to obtain scores

220 representing four different functional indices (Villéger, Mason \& Mouillot, 2008), which are

221 functional richness (FRic), functional evenness (FEve), functional divergence (FDiv) and

222 functional dispersion (FDis). In this study, we represented FBD using FDis, because this index

223 estimates functional $\beta$-diversity based on average distances to the centroid of multivariate

224 dispersion (Anderson, 2006). FDis has been described as a $\beta$-diversity index which is not

225 affected by species richness, it can handle any number and type of traits and it is little biased by

226 outliers (Anderson, Ellingsen \& McArdle, 2006).

227 We visually controlled the robustness of the FBD estimate by constructing a functional

228 tree (Fig. S1) based on Gower pairwise distances between species, which was calculated in the

229 vegan R-package (Oksanen et al., 2015). We undertook a hierarchical cluster analysis on the 
230 Gower dissimilarity matrix to build an UPGMA functional tree, using the hclust function

231 (argument average) in $\mathrm{R}$.

232 Phylogenetic $\beta$-diversity (PBD). We estimated PBD based on a well-supported

233 phylogenetic hypothesis proposed by Pyron, Burbink \& Wiens (2013). Phylogeny of Squamata

234 reptiles was reconstructed by analyzing 12 concatenated genes ( 5 mtDNA and 7 nuclear) from

235 more than 4,000 species. Levels of clade support were estimated by non-parametric Shimodaira-

236 Hasegawa-Like implementation of the approximate likelihood-ratio test (further details in Pyron,

237 Burbink \& Wiens, 2013). We used the ape R-package (Paradis, 2012) to obtain a subtree

238 composed of the species sampled in this study (Fig. S2).

239 We estimated PD using the phylosor function of the picante R-package (Kembel et al.,

240 2010), which estimates fractions of branch lengths in a phylogenetic tree that are shared among

241 communities (Kembel et al., 2010). The phylosor function returns a pairwise phylogenetic

242 similarity matrix, which was converted to a pairwise distance matrix (1-phylosor matrix) and

243 summarized by PCoA scores.

244 Environmental gradients and inferential analysis. We evaluated the influence of clay

245 content in the soil on the diversity measures because this gradient affects primary production,

246 which influences the overall trophic network (Cintra et al., 2013). Clay content was measured in

247 a pooled $5 \mathrm{~g}$ sample derived from six subsamples per plot, and we used averages per module.

248 Technicians at the Laboratório Temático de Solos e Plantas (LTSP) of the Instituto Nacional de

249 Pesquisas da Amazônia (INPA, Manaus) conducted the physical analyses following standard

250 methods (Embrapa, 2009).

251 The Height Above the Nearest Drainage (HAND) algorithm estimates the depth to the

252 water table, which represents a gradient of relative water potential, in which higher values 
253 indicate large gravitational potential and lower values may reflect soil waterlogging in the

254 absence of drainage. Here we tested the effects of HAND (log-normalized) on snake diversity

255 because vertical and horizontal distances from drainage are correlated in a micro-watershed scale

256 (Schietti et al., 2013), and horizontal distance from drainage was previously identified as an

257 important factor affecting snake assemblages through availability of physiological optimal or

258 prey availability at assemblage (Fraga, Lima \& Magnusson, 2011) and population (Fraga et al.,

$2592013 b$ ) levels in Amazonia. We used percentage of tree cover (log-normalized) because this

260 gradient potentially filters species by their adaptability to variation in habitat openness,

261 considering the variation in factors such as availability of resting and nesting sites (Burger \&

262 Zappalorti, 1986), availability of prey and protection from predators (Webb \& Shine, 1996), and

263 light intensity (Pringle, Webb \& Shine, 2003). The gradients HAND and tree cover were

264 obtained from raster surfaces downloaded from the public repository Ambdata (Amaral et al.,

265 2013; www.dpi.inpe.br/Ambdata).

266 We used temperature of the coldest month and precipitation of the wettest month because

267 climate is often considered as a primary factor determining distribution of biodiversity at

268 numerous spatial and temporal scales. Climate may limit species distribution through

269 physiological filtering, especially in ectothermic animals such as snakes (Blain et al., 2009).

270 Climate data were obtained from raster surfaces downloaded from the Worldclim database (Fick

$271 \&$ Hijmans, 2017). All raster surfaces used in this study have a resolution of $1 \mathrm{~km}$, and values for

272 each gradient were extracted by the raster R-package (Hijmans, 2015) using geographic

273 coordinates per module.

274 Geographic distance has been found to be an important factor driving $\beta$-diversity for

275 several vertebrates, because potentially carries unmeasured environmental variation (Qian \& 
276 Ricklefs, 2012). Our study area covers about 4,400 $\mathrm{km}^{2}$, and therefore we expect spatial

277 autocorrelation in the environmental data. To reduce the effects of geographic distance on the 278 environmental gradients we calculated Euclidean distances between centroid coordinates per 279 module, and reduced dimensionalities using the first axis from a PCoA. The coordinates were 280 used in linear regressions given by gradient $=a+b$ (geographic distance). Residuals from these 281 models were used as independent variables in inferential models to quantity proportions of snake 282 diversity that are explained by environmental variation. We used this approach because multiple283 linear-regressions using raw environmental data as independent variables returned slight spatial 284 autocorrelation in the residuals for TBD (Moran's I = -0.272, P = 0.06), FBD (Moran's I = 285 0.320, $\mathrm{P}=0.02$ ) and PBD (Moran's $\mathrm{I}=-0.261, \mathrm{P}=0.08)$, which was negatively significant $(\mathrm{P}<$ 2860.05 ) in $20-30 \%$ of ten geographic distance classes (Fig. S3). To test for the effects of gradients on the diversity measures we used multiple-linearregression models, that were built following the general formula diversity measure $=a+b_{1}$ (clay content residuals $)+b_{2}(H A N D$ residuals $)+b_{3}($ tree cover residuals $)+b_{4}($ temperature residuals $)$ $290+b_{5}$ (precipitation residuals). The gradients measured are given in different units, so we scaled 291 them using the scale function in $\mathrm{R}$ (Becker, Chambers \& Wilks, 1988). The residuals 292 representing gradients showed little multicollinearity ( $\leq 0.7$ in all cases). We have considered 293 significant relationships at $P \leq 0.05$ after Bonferroni correction. Additional information (e.g., 294 amplitude and average values) on the gradients can be found in the Table S3. gradients on raw distance matrices among sampling units, separately for each diversity measure.

297 This approach was useful to verify the robustness of the results obtained by the multiple linear 298 regressions, considering information loss by dimensionality compression through PCoA. We 
299 constructed the models using taxonomic, functional and phylogenetic distance matrices as

300 dependent variables, and environmental gradients as independent variables, which is equivalent

301 to multiple-multivariate linear regression models (Legendre, Fortin \& Borcard, 2015). We used

302 a permutation test of significance (5000 randomizations) to decide between accept or reject null 303 hypothesis.

304 We also compared the subsets of species that were found per plot in each of the four 305 surveys (2007-2014), to control any effect of temporal variation on the diversity measures. We 306 calculated Forbes pairwise dissimilarities among each survey on each plot, summarized the 307 resulting matrix using PCoA (axis 1), and tested differences among surveys using ANOVA. We 308 set a two-factors model - plot and survey - to decouple assemblage compositions between space 309 and time. We found that differences in assemblage composition are associated with plots $(\mathrm{P}=$ 310 0.03), and plots and surveys interacting with each other $(P=0.01)$, but not with surveys alone (P $311=0.26$ ). This finding demonstrates that the patterns of spatial assemblage structure shown in this 312 study have no bias of assemblages changing over time.

To quantify relationships between different diversity measures we used matrix regression 314 with permutation test of significance (5000 randomizations). The models were set up with the 315 pairwise distance matrices used to summarize TBD, FBD and PBD.

\section{Results}

The first axis of PCoA ordination captured $59 \%$ of the original variance in the raw data

319 used to estimate TBD, and the second axis captured 39\%. However, the variance captured by

320 axis 1 was not related to the environmental variation quantified by the gradients tested $(\mathrm{P}>0.25$

321 in all cases). Therefore, we used axis 2 to represent TBD. PCoA axis 1 captured 100\% of the 
322 variance for $\mathrm{FBD}$ and 30\% for PBD and were used as univariate versions of the diversity

323 measures in the inferential models.

324 The multiple linear regression explained 61 percent (adjusted $\mathrm{R}^{2}$ ) of the variance in TBD

$325\left(F_{5,15}=7.31, P=0.001\right.$, residual standard error $\left.=0.29\right)$. This finding was particularly associated

326 to the effects of clay content $(P=0.002)$ and tree cover $(P=0.034)$ on $\beta$-diversity among the

327 sampling modules. HAND, temperature and precipitation were not related to TBD $(P>0.45$ in

328 all cases). About 37 percent of the variance in FBD was explained by the multiple regression

$329\left(F_{5,15}=3.42, P=0.02\right.$, residual standard error $\left.=0.45\right)$, which was mainly due to the effects of

330 HAND $(P=0.023)$ on dissimilarities between modules. Clay content, tree cover, temperature

331 and precipitation were not related to $\operatorname{FBD}(P>0.85$ in all cases). About 32 percent of the

332 variance in PBD was explained by the gradients $\left(F_{5,15}=2.87, P=0.05\right.$, residual standard error $=$

333 0.11), but only HAND $(P=0.034)$ contributed to the model. The other gradients tested were not

334 related to $\operatorname{PBD}(P=1$ in all cases $)$. All the multiple regression models returned residuals that did 335 not differ statistically from a normal distribution (Shapiro-Wilk $W>0.92, P>0.12$ in all cases).

336 A complete summary of the multiple-regression models can be found in Table 1 and the partial

337 regressions from each model are presented in Fig. 2.

The RDA models significantly captured $32 \%$ of the constrained variance to TBD $\left(\mathrm{F}_{5-15}=\right.$

$1.42, \mathrm{P}=0.05), 43 \%$ to $\mathrm{FBD}\left(\mathrm{F}_{5-15}=2.27, \mathrm{P}=0.04\right)$ and $36 \%$ to $\mathrm{PBD}\left(\mathrm{F}_{5-15}=1.71, \mathrm{P}=0.03\right) . \mathrm{In}$

340 general, the results were consistent with the multiple regressions (Table S4). However, tree cover

341 did not significantly explain TBD $(\mathrm{P}=0.24)$.

342 All diversity measures were positively related to each other (Fig. 3). However, TBD was

343 more strongly related to PBD $\left(r^{2}=0.67, P<0.0001\right)$ compare to the relationships between TBD

344 and FBD $\left(r^{2}=0.13, P<0.0001\right)$, and between FBD and PBD $\left(r^{2}=0.23, P<0.0001\right)$. 
346

347

348

349

350

351

352

353

354

355

356

357

358

359

360

361

362

363

364

365

366

367

\section{Discussion}

Our data indicate that environmental gradients affect snake co-occurrence in central-southern Amazonia, which results in levels of $\beta$-diversity identified by taxonomic, functional and phylogenetic dissimilarities among modules. These findings are consistent with temperate snake assemblages, which may be structured by phylogenetic species variability and trait variability (Burbrink \& Myers, 2015). Furthermore, our data corroborate a previous study in Brazil, which found variation in phylogenetic and phenotypic compositions of snake assemblages associated with environmental gradients (Cavalheri, Both \& Martins, 2015). However, the variation found in that study was primarily due to differences between forested and open biomes, which is expected to be pronounced. In this study, we show that variation in snake assemblages along environmental gradients is consistent even within biomes, where structural differences between sites are often subtle.

Environmental gradients affecting species composition have been found in many groups of organisms in the Amazon, such as frogs (Ribeiro-Jr, Lima \& Magnusson, 2012, Rojas-Ahumada, Landeiro \& Menin, 2012), understory birds (Bueno et al., 2012; Menger et al., 2017), plants (Drucker, Costa \& Magnusson, 2008; Moulatlet et al., 2014) and snakes (Fraga, Lima \& Magnusson, 2011). In general, it is expected that species occupy portions of gradients in a way to optimize the balance between dispersal capacity, physiological needs and availability of resources (Laliberté, Legendre \& Shipley, 2014). However, our data indicate that TBD is affected by different sets of environmental gradients compared to FBD or PBD, which suggests that patterns of spatial structure in snake assemblages in the Amazon may not be characterized by a single diversity measure. In fact, choosing environmental gradients as predictors in species- 
368 habitat association models is not a trivial task, although it is an effective approach to evaluate

369 conservation issues such as environmental legislation (Fraga et al., 2011; Bueno et al., 2012).

370 We found that clay content in the soil predicted snake community assembly based on

371 taxonomic dissimilarities among modules. Associations between soil texture and patterns of

372 vertebrate community structure are often assumed as indirectly causal, because soil texture

373 affects many factors driving regional species occurrence, such as vegetation density (Woinarski,

374 Fisher \& Milne, 1999) and distance from streams (Bueno et al., 2012). The environmental

375 heterogeneity in the Amazon rainforests include soil texture gradients from poorly-drained,

376 seasonally-flooded sandy soils (Cintra et al., 2013), in which plants find poor substrate for

377 rooting (Quesada et al., 2012), to well-drained soils that support older well-developed forests

378 (Castilho et al., 2006; Emilio et al., 2013). Therefore, variation in soil texture across landscapes

379 generates high $\beta$-diversity via suitability of the conditions for dispersal and colonization, which

380 has been found in plant (Costa, Magnusson \& Luizão, 2005; Costa et al., 2008), invertebrate

381 (Franklin, Magnusson \& Luizão, 2005) and vertebrate (Woinarski, Fisher \& Milne, 1999; Bueno

382 et al., 2012; this study) assemblages.

383 We showed that HAND is related to snake assemblages based on functional traits and

384 phylogeny. Distance above the drainage has been identified as an important factor structuring

385 plant (Drucker, Costa \& Magnusson, 2008) and animal (Fraga, Lima \& Magnusson, 2011;

386 Bueno et al., 2012; Rojas-Ahumada, Landeiro \& Menin, 2012) assemblages in the Amazon, and

387 riparian zones may be biologically distinct from adjacent areas (Sabo et al., 2005). Despite the

388 fact that most Amazonian snakes can cross different habitats, distance from drainage may

389 influences $\beta$-diversity (Fraga, Lima \& Magnusson, 2011) and structures populations in terms of

390 variation in density and body size (Fraga et al., 2013b). In this study, we found that HAND 
391 affects FBD mainly because lower distances from drainage favor assemblages composed by

392 arboreal (e.g., Imantodes lentiferus) and aquatic species (e.g., Helicops angulatus). Lower values

393 of HAND are often associated with seasonal surface waterlogging (Schietti et al., 2013), which

394 may complicate fossorial and terrestrial lifestyles. Therefore, variation in HAND across the

395 landscape generates regional dispersal corridors that may be more suitable for some species than

396 others, which could affect FBD and PBD.

397 We found inconsistency between the effects of tree cover on TBD estimated by multiple

398 regression and RDA. Different results may reflect different levels of statistical sensitivity of the

399 models to the data structure, or unidentified sampling bias. Therefore, we assume tree cover in

400 this study as a probable filter to snake regional co-occurrence. Variation in tree cover along

401 continuous landscapes generates mosaics of more and less suitable habitats for different subsets

402 of species, through factors that directly affects species biology. These include availability

403 (Lindenmayer et al., 1991) and non-random selection of nesting and resting sites (Burger \&

404 Zappalorti, 1986; Webb \& Shine, 1996), thermo-regulatory requirements, availability of prey,

405 scent chemical trails from potential prey (e.g., small mammals), protection from predators (Webb

$406 \&$ Shine, 1996), variation in light intensity, air and ground temperatures and wind speed (Pringle,

407 Webb \& Shine, 2003). Furthermore, variation in tree cover at wider spatial scales (e.g., biomes)

408 may define regional subsets of species according to their morphological adaptation to use

409 different plant strata (Cavalheri, Both \& Martins, 2015). This finding is relevant for

410 conservation, because maintenance of regional assemblages depends on protecting large areas,

411 which contain wide amplitudes of tree-cover gradients.

412 Changes in phylogenetic (PBD) composition among plots were proportional to changes in the

413 snake taxonomic identities (TBD). Spatial congruence between estimates of phylogenetic and 
414 taxonomic $\beta$-diversity has been suggested as often higher compared to $\alpha$-diversity measures

415 (Devictor et al., 2010; Bernard-Verdier et al., 2013; Arnan, Cerdá \& Retana, 2016), especially

416 in cases of niche conservatism (Wiens \& Graham, 2005). The tendency of species to retain

417 ancestral characteristics along generations results in local or regional assemblages structured by

418 environmental filtering, despite different environmental gradients may affect different diversity

419 measures (Webb et al., 2002). Additionally, the positive correlations between diversity measures

420 show that TBD and FBD efficiently captured a phylogenetic signal, which suggests assemblages

421 evolutionary structured by Brownian motion, in which species change mainly through genetic

422 drift and natural selection randomly directed (Losos, 2008). Concerning the positive relation

423 between FBD and PBD, we found that environmental gradients drive co-occurrence of species

424 that are simultaneously phylogenetically related and have similar ecological requirements

425 (Keddy, 1992; Myers \& Harms, 2009), and one measure may be used as a proxy to the other.

426 Contrarily, TBD was not a good proxy for FBD, because large proportions of data were poorly

427 fitted between both diversity measures. Ultimately, combinations of TBD and FBD should be

428 part of studies on community ecology, because they give integrative approaches that reveal

429 taxonomic, ecological and evolutionary forces acting on community structuring, which is very

430 useful for conservation (Devictor et al., 2010).

431 From the point of view of conservation, the positive relationships between diversity measures

432 directs the focus of biodiversity monitoring programs and reserve planning to cover higher levels

433 of phylogenetic diversity, because this measure reflects the maintenance of ecosystem processes

434 operating over long timescales (Cadotte, Carscadden \& Mirotchnick, 2011). Functional diversity

435 is estimated based on sets of traits that reflect environmental tolerances and requirements, which

436 in turn determine where species can live (Lavorel et al., 1997) and interact with each other in 
437 assemblages (Davies et al., 2007). Therefore, loss of evolutionarily distinct species may result in

438 irreversible loss of functions for ecosystems (Bracken \& Low, 2012). However, at larger scales it

439 may be difficult to decide which diversity measure should be prioritized in conservation, and a

440 multi-dimensional approach may be more appropriate (Devictor et al., 2010), despite greater

441 difficulties of interpretation.

442 Our findings are unlikely to be biased by the spatial distribution of sampling units (see

443 González-Caro et al., 2012), because the RAPELD system provides regular distribution of plots

444 across the landscape regardless of logistical issues (Magnusson et al., 2013). However, snakes

445 usually have low detection probabilities (Steen, 2010; Fraga et al., 2014), which have been

446 estimated at less than 10 percent for multiple surveys of many Amazonian species in RAPELD

447 plots (Fraga et al., 2014). Low detection probabilities often cause false absences of species from

448 plots, and this may generate misinterpretation of how species respond to landscape change $(G u$

$449 \&$ Swihart, 2003). We are unable to totally discount effects of low detectability on our results.

450 However, the strong relationships between diversity measures and environmental gradients

451 showed that a combination of high sampling effort, different methods used to quantify

452 biodiversity and the use of an appropriate multivariate distance measure may considerably

453 reduce the effect of false absences and return reliable results.

454

455 Conclusions

456 We used an unprecedented standardized sampling effort to show that environmental

457 heterogeneity is associated with $\beta$-diversity in Amazonian-forest snakes. Positive correlations

458 between $\beta$-diversity measures estimated show that PBD alone may be sufficient to investigate

459 spatial structure in Amazonian snake assemblages under taxonomic, functional and phylogenetic 
460 perspectives. However, TBD response to different environmental gradients suggests that testing

461 the effects of a set of environmental gradients on at least two $\beta$-diversity measures can generate

462 deeper understanding of factors causing spatial community assembly. This finding highlights the

463 efficiency of using multi-dimensional approaches to quantify biodiversity in community-level

464 conservation status assessments and decision-making on natural resources management.

465

466 Acknowledgements

467 We thank E. Farias, M.C. Araújo, P.I. Simões, M. Antunes, D. Bower, Pinduca, Neneco, Rubico

468 and Joãozinho for assistance in fieldwork. J.M.C. da Silva and two anonymous reviewers

469 provided valuable comments on a previous version of the manuscript.

470

471 References

472 Alroy J. 2015. A new twist on a very old binary similarity coefficient. Ecology 96:575-586.

473 Amaral S, Costa CB, Arasato LS, Ximenes AC, Rennó CD. 2013. AMBDATA: Variáveis

474 ambientais para Modelos de Distribuição de Espécies (MDEs). Anais do XVI Simpósio

475 Brasileiro de Sensoriamento Remoto (SBSR) 16:6930-6937.

476 Anderson MJ. 2006. Distance-based tests for homogeneity of multivariate dispersions.

$477 \quad$ Biometrics 62:245-253.

478 Anderson, MJ, Ellingsen KE, McArdle BH. 2006. Multivariate dispersion as a measure of beta 479 diversity. Ecology Letters. 9:683-693.

480 Arnan X, Cerdá X, Retana J. 2017. Relationships among taxonomic, functional, and 481 phylogenetic ant diversity across the biogeographic regions in Europe. Ecography 40:448482457. 
483 Becker, RA, Chambers JM, Wilks AR. 1988. The new S language: a programming

484 environment for data analysis and graphics. Wadsworth \& Brooks/Cole.

485 Beebe W. 1946. Field notes on the snakes of Kartabo, British Guiana, and Caripito, Venezuela.

$486 \quad$ Zoologica 31:11-52.

487

488

489

490

491

492

493

494

495

496

497

498

499

500

501

502

503

504

505

Belluomini, HE, Hoge AR. 1958. Contribuição à biologia de Eunectes murinus (Linnaeus 1758) (Serpentes). Observações sobre hábitos alimentares de "sucuris" em cativeiro. Memórias do Instituto Butantan 28:207-216.

Bernard-Verdier M, Flores O, Navas M-L, Garnier E. 2013. Partitioning phylogenetic and functional diversity into alpha and beta components along an environmental gradient in a Mediterranean rangeland. Journal of Vegetation Science 25(5):877-889.

Bernarde PS, Albuquerque S, Barros TS, Turci LCB. 2012. Serpentes do estado de Rondônia. Biota Neotropica 12:1-29.

Blain H-A, Bailon S, Cuenca-Bescós G, Arsuaga JL, Castro JMB, Carbonell E. 2009. Longterm climate record inferred from early-middle Pleistocene amphibian and squamate reptile assemblages at the Gran Dolina Cave, Atapuerca, Spain. Journal of Human Evolution 56:55-65.

Bracken MES, Low NHN. 2012. Realistic of rare species disproportionately impact higher trophic levels. Ecology Letters 15:461-467.

Bueno AS, Bruno RS, Pimentel TP, Sanaiotti TM, Magnusson WE. 2012. The width of riparian habitats for understory birds in an Amazonian forest. Ecological Applications 22:722-734.

Burbrink FT, Myers EA. 2015. Both traits and phylogenetic history influence community structure in snakes over steep environmental gradients. Ecography 38:001-013. 
506 Burger J, Zappalorti RT. 1986. Nest site selection by Pine Snakes, Pituophis melanoleucus, in 507 the New Jersey Pine Barrens. Copeia 1986:116-121.

508 Cadotte MW, Cavenders-Bares J, Tilman D, Oakley TH. 2009. Using phylogenetic, 509 functional and trait diversity to understand patterns of plant community productivity. PloS 510 ONE 4:e5695.

511 Cadotte MW, Carscadden K, Mirotchnick N. 2011. Beyond species: functional diversity and 512 513 the maintenance of ecological processes and services. Journal of Applied Ecology 48:1079-

\section{Castilho CV, Magnusson WE, De-Araújo RNO, Luizão RCC, Luizão FJ, Lima AP,}

515 Higuchi N, De-Castilho CV. 2006. Variation in aboveground tree live biomassina central 516 Amazonian forest: effects of soil and topography. Forest Ecology and Management 234:8551796.

518 Cavalheri H, Both C, Martins M. 2015. Filtering and spatial processes in structuring 519 communities: the case of Neotropical snake communities. PLoS ONE 10:e127959.

520 Cintra BBL, Schietti J, Emillio T, Martins D, Moulatlet G, Souza P, Levis C, Quesada CA, 521 Schöngart J. 2013. Soil physical restrictions and hydrology regulate stand age and wood 522 biomass turnover rates of Purus-Madeira interfluvial wetlands in Amazonia. Biogeosciences $523 \quad$ 10:7759-7774.

524 Costa FRC, Magnusson WE, Luizão RC. 2005. Mesoscale distribution of Amazonian 525 understory herbs in relation to topography, soil and watersheds. Journal of Ecology 93:863$526 \quad 878$. 
527 Costa FRC, Guillaumet JL, Lima AP, Pereira OS. 2008. Gradients within gradients: the

528 mesoscale distribution patterns of palms in a central Amazonian forest. Journal of

$529 \quad$ Vegetation Science 20:69-78.

530 Cunha OR, Nascimento FP. 1983. Ofídios da Amazônia XIX - As espécies de Oxyrhopus

531 Wagler, com uma subspécie nova, e Pseudoboa Schneider, na Amazônia oriental e

532 Maranhão. (Ophidia, Colubridae). Boletim do Museu Paraense Emílio Goeldi, série

533 Zoologia 122:1-42.

534 Cunha OR, Nascimento FP. 1993. Ofídios da Amazônia: As cobras da região leste do Pará.

535 Boletim do Museu Paraense Emílio Goeldi, série Zoologia 9:1-191.

536 Davies TJ, Meiri S, Barraclough TG, Gittleman JL. 2007. Species co-existence and character

537 divergence across carnivores. Ecology Letters 10:146-152.

538 Dehling DM, Fritz SA, Töpfer T, Päckert M, Estler P, Böhning-Gaese K, Schleuning M.

539 2014. Functional and phylogenetic diversity and assemblage structure of frugivorous birds

540 along an elevational gradient in the tropical Andes. Ecography 37:1047-1055.

541 Devictor V, Mouillot D, Meynard C, Jiguet F, Thuiller W, Mouquet N. 2010. Spatial

542 mismatch and congruence between taxonomic, phylogenetic and functional diversity: the

543 need for integrative conservation strategies in a changing world. Ecology Letters 13:1030-

$544 \quad 1040$.

545 Dias-Terceiro RG, Kaefer IL, Fraga R, Araújo MC, Simões PI, Lima AP. 2015. A matter of

546 scale: historical and environmental factors structure anuran assemblages from the upper

547 Madeira River, Amazonia. Biotropica 47:259-266.

548 Diaz S, Cabido M. 2001. Vive la difference: plant functional diversity matters to ecosystem

549 processes. Trends in Ecology and Evolution 16:646-655. 
550 Dixon JR, Soini P. 1986. The reptiles of the upper Amazon Basin, Iquitos region, Peru.

$551 \quad$ Milwaukee: Milwaukee Public Museum.

552 Drucker DP, Costa F, Magnusson WE. 2008. How wide is the riparian zone of small streams

553 in tropical forests? A test with terrestrial herbs. Journal of Tropical Ecology 24:65-74.

554 Duellman WE. 1978. The biology of an equatorial herpetofauna in Amazonian Ecuador.

555 Miscellaneous Publications, Museum of Natural History, University of Kansas 65:1-352.

556 Emilio T, Quesada CAN, Costa F, Magnusson WE, Schietti J, Feldpausch TR, Brienen RJW, Baker TR, Chave J, Álvarez E, Araújo A, Bánki O, Castilho CV, Honório C, Euridice N, Killeen TJ, Malhi Y, Mendoza EMO, Monteagudo A, Neill D, Parada GA, Peña-Cruz A, Ramirez-Angulo H, Schwarz M, Silveira M, Ter SH, Terborgh JW, Thomas R, Lezama AR, Vilanova E, Phillips OL. 2013. Soil physical conditions limit palm and tree basal area in Amazonian forests. Plant Ecology \& Diversity 8:229-241.

Empresa Brasileira de Pesquisa Agropecuária (Embrapa). 2009. Manual de análises químicas de solos, plantas e fertilizantes. Brasília: Embrapa Informação Tecnológica, Embrapa Solos.

Fearnside PM. 2014. Impacts of Brazil's Madeira river dams: unlearned lessons for hydroelectric development in Amazonia. Environmental Science \& Policy 38:164-172.

Fearnside PM, Graça PMLA. 2006. BR-319: Brazil's Manaus-Porto Velho highway and the potential impact of linking the arc of deforestation to central Amazonia. Environmental Management 38:705-16.

570 Fick SE, Hijmans RJ. 2017. Worldclim 2: new 1-km spatial resolution climate surfaces for 571 global land areas. International Journal of Climatology 37(12):4302-4315. 
572 Flynn DFB, Mirotchnick N, Jain M, Palmer MI, Naeem S. 2011. Functional and phylogenetic

573 diversity as predictors of biodiversity-ecosystem function relationships. Ecology 92:1573-

$574 \quad 1581$

575 Forbes SA. 1907. On the local distribution of certain Illinois fishes: an essay in statistical 576 ecology. Bulletin of the Illinois State Laboratory of Natural History 7:272-303.

577 Fraga R, Lima AP, Magnusson WE. 2011. Mesoscale spatial ecology in a tropical snake 578

579 assemblage: the width of riparian corridors in central Amazon. Herpetological Journal

580 21:51-57.

Fraga R, Lima AP, Prudente ALC, Magnusson WE. 2013a. Guide to the snakes of the Manaus region - central Amazonia. Manaus: INPA.

582

583

584

585

586

587

588

589

590

591

592

593

594

Fraga R, Magnusson WE, Abrahão CR, Sanaiotti T, Lima AP. 2013b. Habitat selection by Bothrops atrox (Serpentes: Viperidae) in central Amazonia, Brazil. Copeia 2013:684-690.

Fraga R, Stow AJ, Magnusson WE, Lima AP. 2014. The costs of evaluating species densities and composition of snakes to assess development impacts in Amazonia. PloS ONE 9:e105453.

Fraga R, Lima AP, Magnusson WE, Ferrão M, Stow AJ. 2017. Contrasting patterns of gene flow for Amazonian snakes that actively forage and those that wait in ambush. Journal of Heredity 108:524-534.

Franklin E, Magnusson WE, Luizão FJ. 2005. Relative effects of biotic and abiotic factors on the composition of soil invertebrate communities in an Amazonian savanna. Applied Soil Ecology 29:259-273.

Gauch HG. 1982. Multivariate analysis in community ecology. Cambridge: Cambridge University Press. 
595 Gibbons JW, Scott DE, Ryan TJ, Buhlmann KA, Tubervilee TD, Metts BS, Greene JL,

596 Mills T, Leiden Y, Poppy S, Winne CT. 2000. The global decline of reptiles, déjà vu 597 amphibians. BioScience 50:653-666.

598 González-Caro S, Parra JL, Graham CH, McGuire JA, Cadena CD. 2012. Sensitivity of 599 metrics of phylogenetic structure to scale, source of data and species pool of hummingbird $600 \quad$ assemblages along elevational gradients. PloS ONE 7:e35472.

601 Grass I, Brandl R, Botzat A, Neuschulz EL, Farwig N. 2015. Contrasting taxonomic and 602 phylogenetic diversity responses to forest modifications: comparisons of taxa and successive 603 plant life stages in South African scarp forest. PloS ONE 10:e0118722.

Gu W, Swihart RK. 2003. Absent or undetected? Effects of non-detection of species occurrence on wildlife-habitats models. Biological Conservation 116:195-203. Available at http://CRAN.R-project.org/package=raster (accessed on 10 April 2018).

Hoorn C, Wesselingh FP, ter Steege H, Bermudez MA, Moura A, Sevink J, Sanmartín I, Hangartner S, Laurila A, Räsänen K. 2012. Adaptive divergence in moor frog (Rana arvalis) populations along an acidification gradient: inferences from QST - FST correlations. Evolution 66:867-881.

Hijmans RJ. 2015. raster: Geographic Data Analysis and Modeling. R package version 2.3-40. Sanchez-Meseguer A, Anderson CL, Figueiredo JP, Jaramillo C, Riff D, Negri FR, Hooghiemstra H, Lundberg J, Stadler T, Särkinen T, Antonelli A. 2010. Amazonian

616 Jetz W, Fine PVA. 2012. Global gradients in vertebrate diversity predicted by historical area617 productivity dynamics and contemporary environment. PLOS Biology 10(3):e1001292. 
618 Keddy PA. 1992. Assembly and response rules: two goals for predictive community ecology.

619 Journal of Vegetation Science 3:157-164.

620 Kembel SW, Cowan PD, Helmus MR, Cornwell, Morlon H, Ackerly DD, Blomberg SP,

621 Webb CO. 2010. Picante: R tools for integrating phylogenies and ecology. Bioinformatics

622 26:1463-1464.

623 Kinnup VF, Magnusson WE. 2005. Spatial patterns in the understory shrub genus Psychotria

624 in central Amazonia: effects of distance and topography. Journal of Tropical Ecology 21:162512.

626 Laliberté E, Legendre P. 2010. A distance-based framework for measuring functional diversity 627 from multiple traits. Ecology 91:299-305.

628 Laliberté E, Legendre P, Shipley B. 2014. FD: measuring functional diversity from multiple 629 traits, and other tools for functional ecology. R package version 1.0-12. Available at 630 http://CRAN.R-project.org/web/packages/FD (accessed on 10 April 2018).

631 Lavorel S, McIntyre S, Landsberg J, Forbes TDA. 1997. Plant functional classifications: from 632 general groups to specific groups based on response to disturbance. Trends in Ecology and 633 Evolution 12:474-478.

634 Legendre P, Fortin M-J, Borcard D. 2015. Should the Mantel test be used in spatial analysis? 635 Methods in Ecology and Evolution 6:1239-1247.

636 Lindenmayer DB, Cunninham RB, Tanton MT, Smith AP. 1991. The conservation of 637 arboreal marsupials in the montane ash forest of the central highlands of Victoria, south-east 638 Australia, III. Models of the habitat requirements of Leadbeater's possum Gymnobelideus 639 leadbeateri and the diversity and abundance of arboreal marsupials. Biological Conservation $640 \quad 56: 295-315$. 
641 Losos, J. 2008. Phylogenetic niche conservatism, phylogenetic signal and the relationship

642 between phylogenetic relatedness and ecological similarity among species. Ecology Letters

$643 \quad 11: 995-1007$.

644 Magnusson WE, Lima AP, Luizão R, Luizão F, Costa FRC, Castilho CV, Kinupp VF.

645 2005. RAPELD: a modification of the Gentry method for biodiversity surveys in long-term

646 ecological research sites. Biota Neotropica 5(2):1-6.

647 Magnusson WE, Braga-Neto R, Pezzini F, Baccaro F, Bergallo H, Penha J, Rodrigues D,

648 Verdade LM, Lima A, Albernaz AL, Hero J-M, Lawson B, Castilho C, Drucker D,

649 Franklin E, Mendonça F, Costa F, Galdino G, Castley G, Zuanon J, Vale J, Luizão L,

650 Luizão R, Cintra R, Barbosa RI, Lisboa A, Koblitz RV, Cunha CN, Pontes ARM. 2013.

651 Biodiversity and Integrated Environmental Monitoring. Manaus: Áttema.

652 Mariac C, Jehin L, Saïdou AA, Thuillet AC, Couderc M, Sire P, Judgé H, Adam H,

653 Bezançon G, Pham JL, Vigouroux Y. 2011. Genetics basis of pearl millet adaptation along

654 an environmental gradient investigated by a combination of genome scan and association

655 mapping. Molecular Ecology 20:80-91.

656 Martins M, Oliveira ME. 1999. Natural history of snakes in forests of the Manaus region,

657 Central Amazonia, Brazil. Herpetological Natural History 6:78-150.

658 McGill BJ, Enquist BJ, Weiher E, Westoby M. 2006. Rebuilding community ecology from

659 functional traits. Trends in Ecology and Evolution 21:178-185.

660 Menger J, Magnusson WE, Anderson MJ, Schlegel M, Pe’er G, Henle K. 2017.

661 Environmental characteristics drive variation in Amazonian understory bird assemblages.

$662 \quad$ PLOS ONE 12:e0171540. 
663 Meynard CN, Devictor V, Mouillot D, Thuiller W, Jiguet F, Mouquet N. 2011. Beyond

664 taxonomic diversity patterns: how do $\alpha, \beta$ and $\gamma$ components of bird functional and

665 phylogenetic diversity respond to environmental gradients across France? Global Ecology

666 and Biogeography 20:893-903.

667 Michaud EJ, and Dixon JR. 1989. Prey items of 20 species of the Neotropical colubrid snake 668 genus Liophis. Herpetological Review 20:39-41.

669 Milcu A, Allan E, Roscher C, Jenkins T, Meyer ST, Flynn D, Bessler H, Buscot F, Engels

670 C, Gubsch M, König S, Lipowsky A, Loranger J, Renker C, Scherber C, Schmid B,

671 Thébault E, Wubet T, Weisser WW, Scheu S, Eisenhauer N. 2013. Functionally and

672 phylogenetically diverse plant communities key to soil biota. Ecology 94:1878-1885.

673 Morlon H, Schwilk DW, Bryant JA, Marquet PA, Rebelo AG, Tauss C, Bohannan BJM,

674

Green JL. 2011. Spatial patterns of phylogenetic diversity. Ecology Letters 14(2):141-149.

675

Moulatlet GM, Costa FRC, Rennó CD, Emílio T, Schietti J. 2014. Local hydrological

676 conditions explain floristic composition in lowland Amazonian forests. Biotropica 46:395-

677 403.

678

Myers JA, Harms KE. 2009. Seed arrival, ecological filters, and plant species richness: a metaanalysis. Ecology Letters 12:1250-1260.

Oksanen J, Blanchet FG, Friendly M, Kindt R, Legendre P, McGlinn D, Minchin PR, April 2018).

Petchey OL, Gaston KJ. 2002. Functional diversity (FD), species richness and community composition. Ecology Letters 5:402-411. 
686 Petchey OL, Gaston KJ. 2006. Functional diversity: back to basics and looking forward.

687

688

689

690

691

692

693

694

695

696

697

698

699

700

701

702

703

704

705

706

707

708 Ecology Letters 9:741-758.

Petchey OL, Gaston KJ. 2007. Dendrograms and measuring functional diversity. Oikos 116:1422-1426.

Pressey RL, Humphries CJ, Margules CR, Vane-Wright RI, Williams PH. 1993. Beyond opportunism: key principles for systematic reserve selection. Trends in Ecology and Evolution. 8:124-128.

Pringle RM, Webb JK, Shine R. 2003. Canopy structure, microclimate, and habitat selection by a nocturnal snake, Hoplocephalus bungaroides. Ecology 84:2668-2679.

Pyron RA, Burbink FT, Wiens JJ. 2013. A phylogeny and revised classification of Squamata, including 4161 species of lizards and snakes. BMC Evolutionary Biology 13:1-53.

Qian H, Ricklefs RE. 2012. Disentangling the effects of geographic distance and environmental dissimilarities on global patterns of species turnover. Global Ecology and Biogeography 21:341-351.

Quesada CA, Phillips OL, Schwarz M, Czimczik CI, Baker TR, Patiño S, Fyllas NM, Hodnett MG, Herrera R, Almeida S, Alvarez DE, Arneth A, Arroyo L, Chao KJ, Dezzeo N, Erwin T, Di-Fiore A, Higuchi N, Coronado EH, Jimenez EM, Killeen T, Lezama AT, Lloyd G, López-González G, Luizão FJ, Malhi Y, Monteagudo A, Neill DA, Vargas PN, Paiva R, Peacock J, Peñuela MC, Cruz AP, Pitman N, Filho NP, Pietro A, Ramírez H, Rudas A, Salomão R, Santos AJB, Schmerler J, Silva N, Silveira M, Vásquez R, Vieira I, Terborgh J, Lloyd J. 2012. Basin-wide variations in Amazon forest structure and function are mediated by both soils and climate. Biogeosciences 9:22032246. 
709 R Development Core Team. 2015. R: a language and environment for statistical computing.

710 Vienna: R Foundation for Statistical Computing. Available at http://www.R-project.org

$711 \quad$ (accessed on April 10 2018).

712 Ribeiro-Jr JW, Lima AP, Magnusson WE. 2012. The effect of riparian zones on species 713 diversity of frogs in Amazonian forests. Copeia 2012:375-381.

714 Rojas-Ahumada DP, Landeiro VL, Menin M. 2012. Role of environmental and spatial 715 processes in structuring anuran communities across a tropical rainforest. Austral Ecology $716 \quad 37: 865-873$.

717 Sabo JL, Sponseller R, Dixon M, Gade K, Harms T, Heffernan J, Jani A, Katz G, Soykan

718 C, Watts J, Welter J. 2005. Riparian zones increase regional species richness by harboring 719 different, not more, species. Ecology 86:56-65.

720 Schietti J, Emilio T, Rennó CD, Drucker DP, Costa FRC, Nogueira A, Baccaro FB, 721 Figueiredo F, Castilho CV, Kinupp V, Guillaumet JL, Garcia ARM, Lima AP, Magnusson WE. 2013. Vertical distance from drainage drives floristic composition changes in an Amazonian rainforest. Plant Ecology \& Diversity 2:241-253.

724

725

726

727

728

729

730

731

Soares-Filho BS, Nepstad DC, Curran LM, Cerqueira GC, Garcia RA, Ramos CA, Voll E, McDonald A, Lefebvre P, Schlesinger P. 2006. Modelling conservation in the Amazon basin. Nature 440:520-523.

Starace F. 1998. Guide des Serpents at Amphisbènes de Guiane. Matoury: Ibis Rouge Éditions.

Steen D. 2010. Snakes in the grass: secretive natural histories defy both conventional and progressive statistics. Herpetological Conservation \& Biology 5:183-188.

Tilman D. 2001. Functional diversity. In: Levin SA, ed. Encyclopedia of Biodiversity. New York: Academic Press, 109-120. 
732 Venables WN, Ripley BD. 2002. Modern applied statistics with S. 4th edition. New York:

$733 \quad$ Springer.

734 Villéger S, Mason WH, Mouillot D. 2008. New multidimensional functional diversity indices

735 for a multifaceted framework in functional ecology. Ecology 89:2290-2301.

736 Webb JK, Shine R. 1996. Out on a limb: conservation implications of tree-hollow use by a

737 threatened snake species (Hoplocephalus bungaroides: Serpentes, Elapidae). Biological

$738 \quad$ Conservation 81:21-33.

739 Weinstein BG, Tinoco B, Parra JL, Brown LM, McGuire JA, Stiles FG, Graham CH. 2014.

740 Taxonomic, phylogenetic, and trait beta diversity in South American Hummingbirds. The

$741 \quad$ American Naturalist 184(2):211-224.

742 Wiens JJ, Graham CH. 2005. Niche conservatism: integrating evolution, ecology, and 743 conservation biology. Annual Review of Ecology, Evolution, and Systematics 36:519-539.

744 Winemmiler KO, López-Fernández H, Taphorn DC, Nico LG, Duque AB. 2008. Fish

745 assemblages of the Casiquiare River, a corridor and zoogeographical filter for dispersal

746 between the Orinoco and the Amazon basins. Journal of Biogeography 35:1551-1563.

747 Woinarski JCZ, Fisher A, Milne D. 1999. Distribution patterns of vertebrates in relation to an

748 extensive rainfall gradient and variation in soil texture in the tropical savannas of the

749 Northern Territory, Australia. Journal of Tropical Ecology 15:381-398. 


\section{Table $\mathbf{1}$ (on next page)}

Summary of statistical coefficients from multiple linear regressions testing the effects of environmental gradients on estimates of snake $\beta$-diversity in Brazilian Amazonia.

$\mathrm{TBD}=$ taxonomic $\beta$-diversity, $\mathrm{FBD}=$ functional $\beta$-diversity, $\mathrm{PBD}=$ phylogenetic $\beta$-diversity . HAND $=$ Height Above the Nearest Drainage. Bolded P-values are statistically significant after Bonferroni correction. $\mathrm{R}^{2}$ values are adjusted to the number of sampling units. $\mathrm{SE}=$ standard error. 
1

2

3

4

5

6

7

8

9

10

11

\begin{tabular}{lcccc} 
& Coefficient & TBD & FBD & PBD \\
\cline { 2 - 5 } & $R^{2}$ & 0.612 & 0.377 & 0.319 \\
\cline { 2 - 5 } Clay content & $P$ & $\mathbf{0 . 0 0 1}$ & $\mathbf{0 . 0 2}$ & $\mathbf{0 . 0 5}$ \\
\hline \multirow{3}{*}{ HAND } & SE & 0.007 & 0.01 & 0.002 \\
& $t$ & -4.431 & -0.499 & 1.233 \\
& $P$ & $\mathbf{0 . 0 0 2}$ & 1 & 1 \\
\hline \multirow{3}{*}{ Tree cover } & $\mathrm{SE}$ & 0.08 & 0.127 & 0.033 \\
& $t$ & -0.045 & 3.325 & 3.142 \\
\multirow{2}{*}{ Temperature of } & $P$ & 1 & $\mathbf{0 . 0 2 3}$ & $\mathbf{0 . 0 3 4}$ \\
the coldest month & $\mathrm{SE}$ & 0.16 & 0.247 & 0.064 \\
& $t$ & 3.929 & -1.435 & 0.661 \\
& $P$ & $\mathbf{0 . 0 0 7}$ & 0.859 & 1 \\
\hline \multirow{2}{*}{ Precipitation of } & $\mathrm{SE}$ & 0.23 & 0.035 & 0.009 \\
the wettest month & $\mathrm{SE}$ & -0.34 & -0.044 & -0.574 \\
& $t$ & 1 & 1 & 1 \\
\hline
\end{tabular}

12

13

14

15

16 
Figure 1

Map of the study area in Brazilian Amazonia showing plots where snake assemblages were sampled.

Black circles are $5 \mathrm{~km}^{2}$ RAPELD sampling modules (see definition of RAPELD in the methods). The numbers can be used to check the species found in each module in Table S1. (A) Ducke Reserve, Manaus. (B) Federal highway BR-319, Purus-Madeira interfluve. (C) Upper Madeira River, Rondônia. 

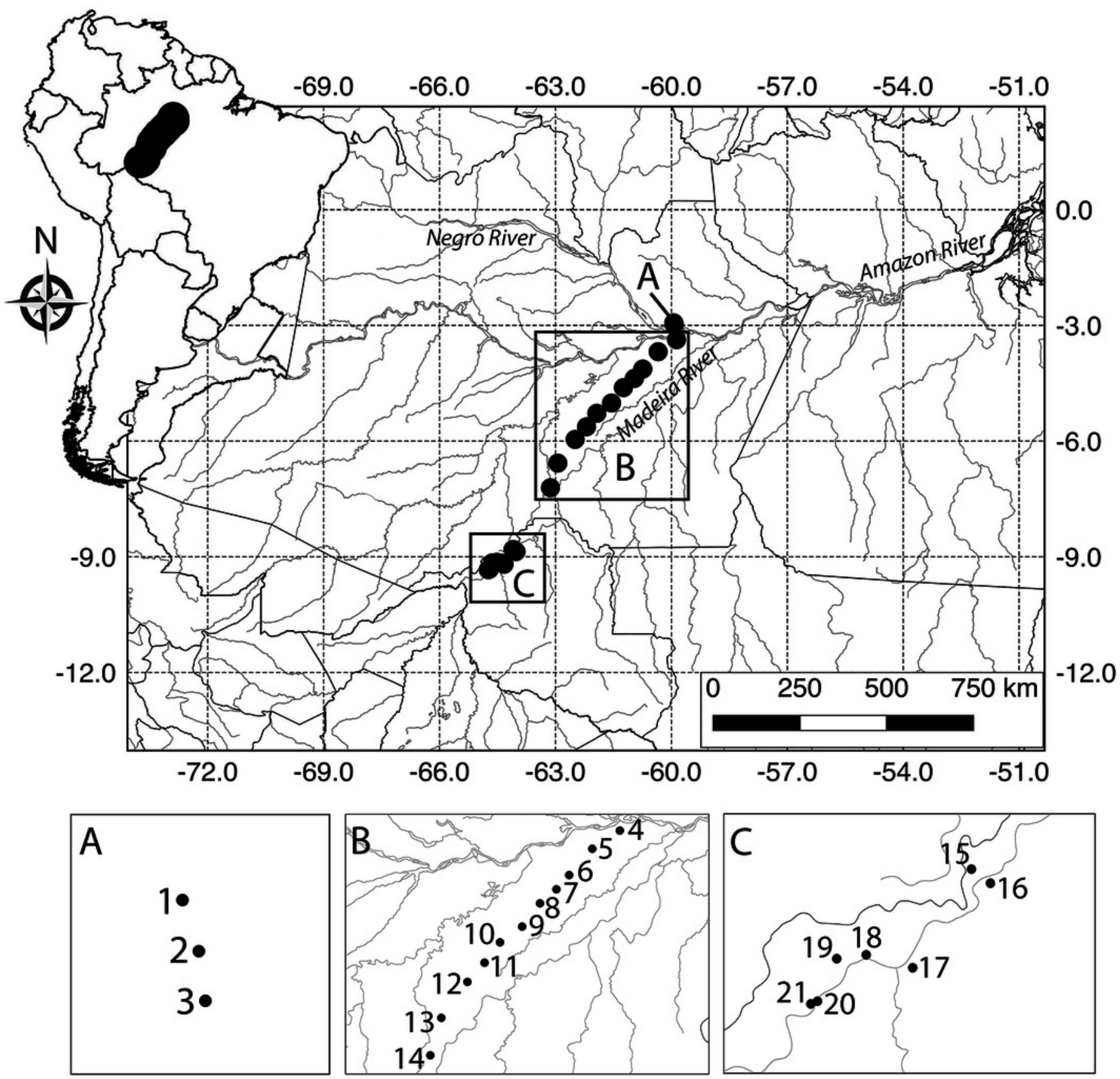
Figure 2

Relationships (partials from multiple linear regressions) between different measures of snake $\beta$-diversity and environmental gradients in central-southwestern Brazilian Amazonia.

(A) TBD = taxonomic $\beta$-diversity, (B) FBD = functional $\beta$-diversity, (C) PBD = phylogenetic $\beta$ diversity. HAND = Height Above the Nearest Drainage. Environmental gradients are shown as residuals from linear regressions used to reduce the effects of geographic distance on the environmental heterogeneity measured.

A

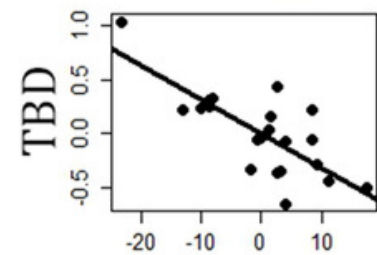

$\mathrm{B}$

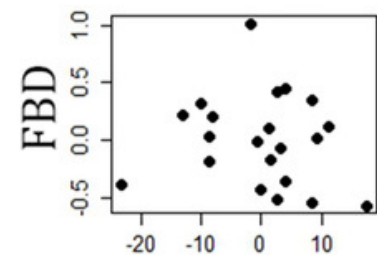

C

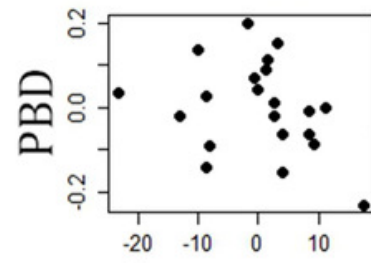

Clay content
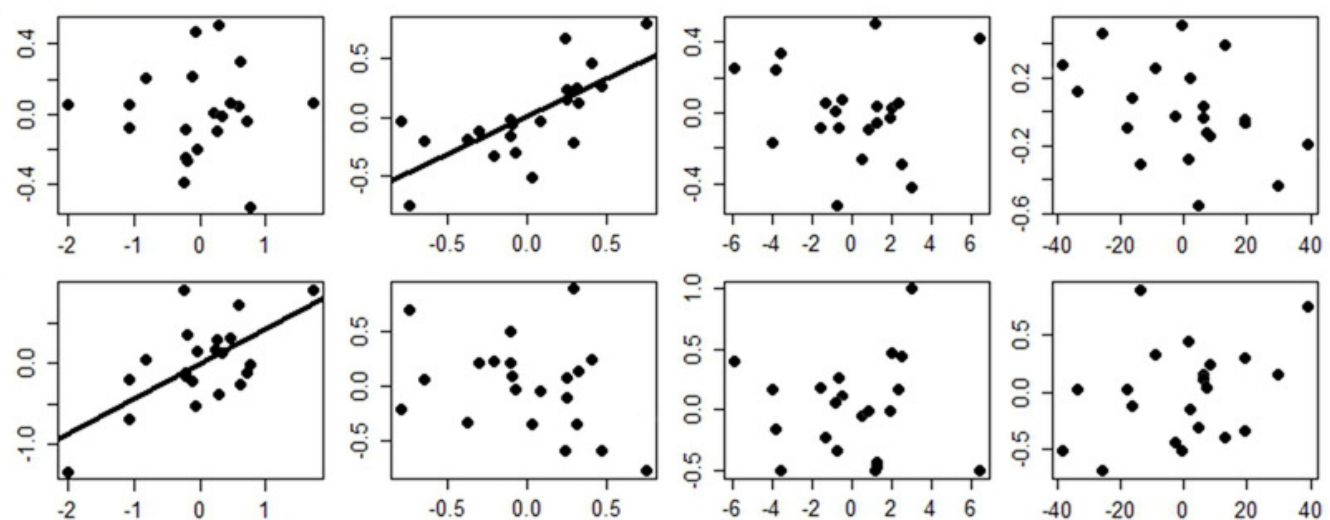

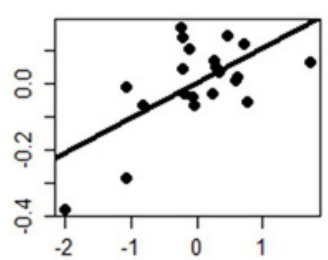

HAND

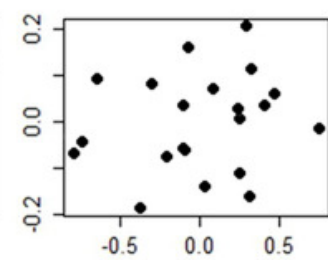

Tree cover

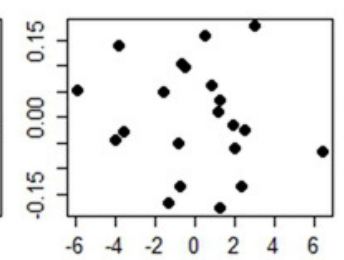

Temperature

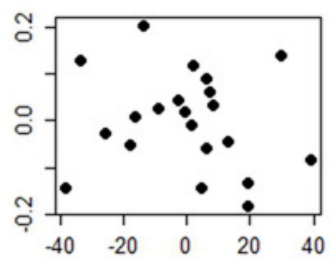

Precipitation 
Figure 3

Relationships between dissimilarity matrices used to summarize different estimates of snake $\beta$-diversity in central-southwestern Brazilian Amazonia.

$\mathrm{TBD}=$ taxonomic $\beta$-diversity, $\mathrm{FBD}=$ functional $\beta$-diversity, $\mathrm{PBD}=$ phylogenetic $\beta$-diversity.

(A) Relationship between TBD and FDB. (B) Relationship between TBD and PBD. (C)

Relationship between FBD and PBD.
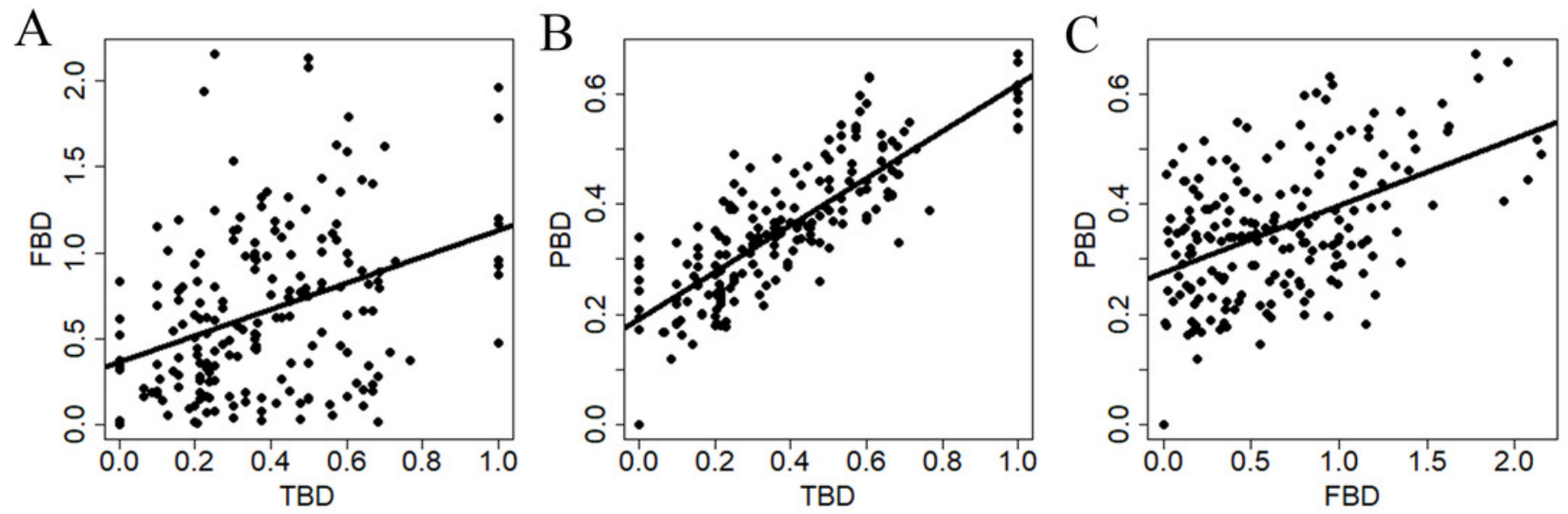